\title{
Central Himalayan rivers record the topographic signature of erosion by glacial lake outburst floods
}

\author{
Maxwell P. Dahlquist ${ }^{1}$ and A. Joshua West ${ }^{2}$ \\ ${ }^{1}$ Department of Earth and Environmental Systems, Sewanee: The University of the South, Sewanee, Tennessee, 37383, USA \\ ${ }^{2}$ Department of Earth Sciences, University of Southern California, Los Angeles, California 90089, USA
}

Correspondence: Maxwell P. Dahlquist (mpdahlqu@ sewanee.edu)

\begin{abstract}
In steep landscapes, river incision sets the pace of landscape evolution. Transport of coarse sediment controls incision by evacuating material delivered to river channels by landslides. However, large landslide-derived boulders that impede bedrock erosion are immobile even in major runoff-driven floods. Glacial lake outburst floods (GLOFs) mobilize these boulders and drive incision, yet their role in regional-scale erosion is poorly understood, largely because of their rarity. Here, we find a topographic signature consistent with widespread GLOF erosion in the Nepal Himalaya. In rivers with glaciated headwaters that generate GLOFs, valleys stay narrow and relatively free of sediment, with bedrock often exposed to erosion. In turn, tributaries to these valleys are steep, allowing less efficient erosional regimes to keep pace with GLOF-driven incision. Where GLOFs are less frequent, valleys are more alluviated and incision stalls. Our results suggest the extent of headwater glaciation may play an important role in erosion of Himalayan river valleys and deserves more attention in future work.
\end{abstract}

\section{Introduction}

\subsection{Motivation}

The erosion of mountainous topography crafts the shape of Earth's surface, influences atmospheric circulation and global climate, modulates global carbon and nutrient fluxes, and affects the tempo of natural hazards including earthquakes and landslides (Raymo and Ruddiman, 1992; Hilton and West, 2020; Steer et al., 2014; Larsen and Montgomery, 2012). At elevations above the equilibrium line altitude (ELA), snow persists from one year to the next, forming glaciers that carve textbook Ushaped valleys (Davis, 1900). Fierce debates have centred on the notion that a "glacial erosion buzz-saw" limits the total height and relief of mountain ranges (Brozović et al., 1997; Egholm et al., 2009; Thomson et al., 2010; Cunningham et al., 2019), but even the proponents of this idea generally assume that the influence of glacial erosion fades below the ELA (Prasicek et al., 2018).

Many studies have noted the dramatic erosive power of GLOFs, which arise from the sudden and catastrophic draining of ice or moraine dammed lakes (Mason, 1929; Haeberli, 1983; Montgomery et al., 2004). The resulting floods can scour river valleys for 10s to 100s of kilometres downstream (Cenderelli and Wohl, 2003; Baynes et al., 2015; Jacquet et al., 2017; Lang et al., 2013; Cook et al., 2018), in some cases mobilizing boulders that otherwise remain stationary even during heavy rainfall-driven flooding (Cook et al., 2018; Xu, 1988). The leading edge of an outburst flood remains below its transport capacity because the 
https://doi.org/10.5194/esurf-2021-54

Preprint. Discussion started: 3 August 2021

(c) Author(s) 2021. CC BY 4.0 License.

velocity of the water bore exceeds that of entrained bedload. Thus, GLOFs remain capable of mobilizing additional material as they progress downstream. These features make GLOFs highly effective incision mechanisms even in low-gradient channels (Cook et al., 2018; Pickering et al., 2019). These events can thus extend the imprint of glacier-associated erosion well below the elevations that support glaciers themselves.

While the dramatic effects of GLOFs have been well-documented, their rarity has made it challenging to identify whether these floods are sufficiently frequent and widespread to play an important role in controlling the long-term evolution of mountain topography. Evidence from glacial lake-derived valley fill and river profiles in the Shyok and Indus valleys suggests that fluvioglacial interactions promote incision into the western edge of the Tibetan Plateau (Scherler et al., 2014). Yet this effect is juxtaposed against the long-term inhibition of erosion as a result of lakes formed by glacial dams (Korup et al., 2010). Here, we evaluate the valley and channel morphology of rivers draining the Nepal Himalaya, finding signatures that are consistent with a systematic role for GLOFs as important agents of long-term erosion. Specifically, we compared rivers that have glaciated (or recently glaciated) headwaters versus those that do not, finding that rivers with glaciated headwaters are distinct both in valley width and channel steepness relationships between tributaries and trunk streams. Furthermore, we observe that knickpoints are concentrated in tributaries more likely to have experienced repeated GLOFs. We attribute these differences to the long-term imprint of repeated GLOFs. Our results suggest "top-down" glacially driven erosion may be important across more of the landscape in major mountain ranges than currently recognized, which would have fundamental implications for the coupling of tectonics, erosion, and landscape evolution, and for the interpretation of tectonic processes from river channel form.

\subsection{Setting: The role of GLOF erosion in the Nepal Himalaya}

The Nepal Himalaya are a leading exemplar of an actively eroding mountain range, offering unique opportunities for understanding the relationships between tectonics, topography, and erosion. The major rivers in Nepal have their headwaters in Tibet and flow across the High Himalaya and Middle Hills, ultimately draining onto the Gangetic Plain (Figure 1A). Tributaries to these rivers drain widely varying topography characterized by diverse geomorphic processes (Whipple and Tucker, 1999; Montgomery and Foufoula-Georgiou, 1993). Many of the major rivers have large areas of glaciated headwaters, and much attention has focused on the hazard posed by increasing GLOF frequency in a warming climate (Korup and Tweed, 2007; Veh et al., 2020). Investigation of the role of GLOFs in shaping this landscape remains limited largely to individual case studies (Cenderelli and Wohl, 2003; Cook et al., 2018), along with identifying sedimentary evidence of past GLOF activity (Pickering et al., 2019; Huber et al., 2020).

To test for a signature of pervasive GLOF control on erosion across the central Nepal Himalaya, we calculated metrics of river profile morphology, specifically (1) normalized channel steepness adjusted for precipitation and evapotranspiration, (2) the prevalence of knickpoints in tributary channels, and (3) valley width and normalized valley wideness. We interpreted the river channel metrics in the context of the upstream drainage area above the last glacial maximum ELA (LGM ELA), estimated to have been 4200 meters in the Nepal Himalaya (Asahi, 2010). We assume that the frequency of GLOFs was proportional to the potentially glaciated terrain in each basin. 
https://doi.org/10.5194/esurf-2021-54

Preprint. Discussion started: 3 August 2021

(c) Author(s) 2021. CC BY 4.0 License.

We used the LGM ELA on the basis that river morphology expressed today reflects the integration of erosional processes over the several thousand years of glacial retreat (Ray and Srivastava, 2010). While outburst floods originating from landslidedammed lakes are also common in the Himalaya and are also important geomorphic agents (Hewitt, 1998), we do not expect an obvious relationship between upstream glaciers and landslide-dammed lakes, so our analysis based on drainage area above the LGM ELA limits our focus to GLOF features. The assumption that drainage area above the ELA is proportional to GLOF frequency is imperfect, since, for example, the extent of glaciation on the Tibetan Plateau during the LGM is debated even though this area lies above the ELA (Kirchner et al., 2011). We account for this particular factor by excluding rivers that drain substantial area of the Tibetan Plateau from our analysis. We also reduce the likelihood of region-to-region variability in GLOF frequency affecting our results, by focusing our study area within the Central Himalaya region which is frequently considered as a coherent unit in hazard analyses of GLOFs (Veh et al., 2019; Fischer et al., 2020). In this region, glacier mass balance (which is intrinsically tied to glacial volume) has been found to be related to the frequency of floods originating in moraine-dammed lakes (Fischer et al., 2020). While the relationship between upstream drainage area above the ELA and outburst flood frequency is likely non-linear, we maintain that it is a reasonable proxy for regional-scale assessment. Upstream glaciers also have an important influence on non-outburst flood runoff, contributing meltwater during the hottest months of the summer, generally during the monsoon months. This meltwater can exacerbate monsoon-driven flooding, which does add a complicating factor (Lutz et al., 2014). However, the immobility of large boulders in monsoon-driven floods still points to GLOFs as an important erosional mechanism.

\subsection{Conceptual model for river morphologic response to GLOF erosion}

At elevations below the extent of glaciation, rivers are the main pacemakers of erosion. The erosive power of rivers is controlled by their base level, which is the lowest elevation of active fluvial erosion. Uplift of mountainous terrain effectively decreases base level, driving rivers to steepen and incise more deeply into uplifting rock. This incision steepens surrounding hillslopes, which respond by eroding faster (Burbank et al., 2003). According to the detachment-limited framework for river evolution, fluvial erosion is driven "from the bottom up," whereby base level change begins at low elevations (e.g., at river outlets) and moves upstream from there, producing a wave of incision and hillslope lowering that works its way through the landscape (Figure 2A-C) (Howard, 1994).

This simple conceptual model finds natural expression in fault-block mountains where uplift is focused on a single fault at the base of the range (Whittaker, 2012). In such settings and under the right conditions, the topographic profiles of rivers preserve quantitative information about the tectonic and geodynamic drivers of uplift, or about past change in climate (Whipple and Tucker, 1999). In more complex mountain ranges, numerous other processes can affect river incision and erosion, including differential rock uplift associated with multiple active tectonic features (Kirby and Whipple, 2001), gradients in precipitation and channel width (Roe et al., 2003; Finnegan et al., 2005), and variations in lithology, rock strength, and sediment availability (Sklar and Dietrich, 2001, 2006). In addition, extreme, infrequent events (such as GLOFs) play key roles in erosion (Kirchner et al., 2001; Cook et al., 2018), yet their role in modulating the response of incision to uplift is poorly understood. 
https://doi.org/10.5194/esurf-2021-54

Preprint. Discussion started: 3 August 2021

(c) Author(s) 2021. CC BY 4.0 License.

\subsection{Morphometric proxies of GLOF erosion}

We test for three predicted effects of GLOF-driven erosion on the topographic form of rivers in the central Himalaya. The first of these is the steepness of river channels. Normalized channel steepness $\left(k_{s n}\right)$ represents the steepness of channels after accounting for the typically concave form of most river profiles. This concave form is reflected in a power law relationship

$S=k_{s} A^{-\theta}$

If $\theta$ is fixed to a best-fit reference value, the normalized channel steepness $k_{s n}$ provides a basis for comparing the relative steepness of different channels (see Methods) (Flint, 1974). Differences in $k_{s n}$ between river segments have been attributed to variations in uplift (faster uplift requires a steeper, more energetic river for incision to keep pace), local rock strength (stronger rocks require more energy to erode), sediment supply (competing effects of tools and cover either enhance or inhibit erosion), and climate (less discharge means less erosive power, requiring steeper channels). Importantly for our purposes, GLOFs may influence $k_{s n}$ because they are highly effective erosional agents even in a low-gradient river. High-magnitude, low-frequency discharge events, of which lake outburst floods are the apotheosis, are recognized as a critical control on erosion and on the geometry of channels, particularly where discharge thresholds for initiation of erosion are high (Snyder et al., 2003; Lague et al., 2005; Turowski et al., 2009; DiBiase and Whipple, 2011). As a result, erosional efficiency can be enhanced under conditions where channel steepness is low, mean discharge and discharge variability are high, and incision thresholds are high (DiBiase and Whipple, 2011). The major rivers of the Nepal Himalaya should meet these conditions, with discharge peaks defined by catastrophic outburst floods and incision thresholds governed by the presence of 10 meter-scale boulders in the channel. We thus expect river segments that are influenced by GLOFs to erode more rapidly than rivers without GLOFs, all other factors being equal, and therefore GLOF-influenced rivers will require lower $k_{s n}$ for the same erosion rate than if runoff-driven floods were the dominant erosional mechanism. If correct, this effect should be detectable in the geometry of the channels (Figure 2D).

Secondly and similarly, we expect GLOF erosion may be associated with discrete steepened reaches (knickpoints) in tributary channels near their outlets into larger trunk streams. In our proposed model for GLOF erosion, knickpoints should form in tributaries a result of pulses of GLOF incision in the trunk stream. A concentration of knickpoints near trunk streams where outburst floods are more frequent would support an erosion model where GLOFs are an important factor. This is not to suggest that outburst floods are the only means by which knickpoints can develop at confluences. Punctuated incision, which may result in steepened reaches developing in tributaries, has been documented at a variety of timescales in rivers with different characteristics (Gardner et al., 1987; Finnegan et al., 2014). However, we hypothesize that outburst flood-driven incision may be particularly effective at generating knickpoints at tributaries due to the magnitude of erosion that may occur in a single event, particularly for rivers where GLOFs are relatively frequent.

Thirdly, the removal of coarse sediment by GLOFs is expected to change river valley widths. We propose that outburst floods facilitate river incision by mobilizing very coarse sediment, including large boulders, that remains stationary even during large runoff-driven floods. The widths of valley floors should reflect the degree of aggradation at longer timescales than the width 
of the active channels (Schwanghart et al., 2016; Yanites, 2018). If floods clear out aggraded material, we expect to see a narrowing trend in rivers subject to more GLOF activity if our erosion model depicted in Figure 2D plays a substantial role of Himalayan river incision. To test this, we analysed valley floor widths based on a discharge-adjusted normalized channel wideness index ( $k_{w n}^{*}$, see Methods) to account for the typical power-law increase in valley width with discharge.

\section{Methods}

We evaluated the metrics described above for a region of central Nepal characterized by N-S trending rivers draining across the Himalayan range (Figure 1). These rivers differ significantly in the extent of upstream glaciated area at the LGM. To complete topographic analysis of this region, we used the Shuttle Radar Topography Mission (SRTM) 30-meter digital elevation model (DEM), patched with the Advanced Spaceborne Thermal Emission and Reflection Radiometer (ASTER) 30-meter DEM where voids exist in SRTM. Topographic metrics were calculated using the TopoToolbox and Topographic Analysis Kit packages for Matlab, and the DEM was preprocessed to remove outliers and impose a minimum downstream gradient for analysis of channel profiles (Forte and Whipple, 2019; Schwanghart and Scherler, 2014).

\subsection{Physical Relationships in Channel Networks}

In actively uplifting landscapes, the geometry of the land surface is governed by competition between uplift and gravity, mediated by a series of processes with a variety of controlling factors. In time, this competition tends to result in stalemate, a time-invariant condition of topographic steady state (Whipple and Tucker, 1999; Willett and Brandon, 2002). For most of the Earth's surface, local boundary conditions for erosion are set by the pace of incision or aggradation associated with river channel processes. In channel networks, the relationship between channel slope and contributing drainage area can reveal the active erosional processes. Downstream reaches of the channel network, which are typically controlled by fluvial processes, are described by the power law function

where $E$ is erosion rate, $K$ is the erosion coefficient, which is governed by local lithology, climate, and the process that control incision in the area, $A$ is drainage area, $S$ is local slope, and $m$ and $n$ are empirical constants which have a range of possible values depending on local conditions. Under steady-state conditions, where uplift and erosion can be assumed to be equal,

$S=(U / K)^{(1 / n)} A^{(m / n)}$

where $U$ is uplift (Whipple and Tucker, 1999). This equation can be recast as Equation 1, known as Flint's Law, where $k_{s}$ defines a channel steepness $(U / K)^{(1 / n)}$. The parameter $\theta$, termed the concavity, which under conditions of spatially invariant uplift and erodibility equals $m / n$, represents the rate of change of channel slope with drainage area and is generally accepted to be insensitive to uplift rate (Flint, 1974). $k_{s}$ varies with uplift rate but contains units that are dependent on $\theta$. In order to make a reasonable comparison of $k_{s}$ among channels with different $\theta$, we must fix the value of $\theta$ to a reference concavity, $\theta_{\text {ref }}$, 
https://doi.org/10.5194/esurf-2021-54

Preprint. Discussion started: 3 August 2021

(c) Author(s) 2021. CC BY 4.0 License.

that represents an average value for the channels in the area of interest, typically between $0.35-0.65$, although this value may vary widely depending on local factors (Wobus et al., 2006a).

\subsection{Adjusted normalized channel steepness index $\left(k_{s n}^{*}\right)$}

Fixing $\theta$ to $\theta_{\text {ref }}$ results in the normalized channel steepness index $k_{s n}$ which is calculated as a best fit value for a given channel reach and is frequently and effectively used as a proxy in broad comparisons of uplift and incision rates across landscapes (Wobus et al., 2006a). However, a key feature of Equation 1 is that drainage area $A$ is used as a proxy for water discharge $Q$, which is the parameter presumed to drive incision. In general, larger drainage areas produce higher discharge, so that $A$ can be assumed directly proportional to $Q$. However, given the dramatic gradient in precipitation from the Gangetic Plain to the Tibetan Plateau, contributing drainage area on its own is not an accurate proxy for discharge in this setting. We used a modified metric, $k_{s n}^{*}$, which accounts for variation in runoff across the region, since runoff may substantially affect $k_{s n}$ (Gasparini and Whipple, 2014). To calculate $k_{s n}^{*}$, we estimated the contributing runoff from each DEM grid cell using mean annual precipitation $(P)$ from a 12-year (1998-2009) Tropical Rainfall Measuring Mission (TRMM) dataset (Bookhagen, 2013) and evapotranspiration (ET) from the Global Land Evaporation Amsterdam Model (GLEAM) (Martens et al., 2017) and used the resulting runoff estimate to weight cells when calculating contributing drainage area. We recast Equation 3 as

$S=k_{s n}^{*} Q^{\left(-\theta_{r e f}^{*}\right)}$

with $Q$ representing estimated discharge from the water balance $(P-E T)$ in each DEM cell. This approach ignores any spatial variation in water storage, which we expect to be small.

Employing our discharge estimate and plotting slope against discharge for all channels across our study area, we found a best-fit $\theta_{r e f}^{*}$ of 0.0781 and used this value for all $k_{s n}^{*}$ calculations in this study. We used the Topographic Analysis Kit to calculate $k_{s n}^{*}$ using the "trib" method, which fits $k_{s n}^{*}$ for channel network segments between confluences individually, calculating tributaries separately from trunk streams for the most accurate representation of $k_{s n}^{*}$ patterns near confluences (Forte and Whipple, 2019). To compare tributary and trunk stream $k_{s n}^{*}$, we take the $k_{s n}^{*}$ value for the tributary at the channel node closest to 200 meters from the confluence (Figure 1B). Given the resolution of the DEM (30 meter grid spacing) and possible orientations of channel nodes, this will be 5-7 nodes from the confluence. We use the $k_{s n}^{*}$ value 200 meters from the confluence to avoid taking tributary $k_{s n}^{*}$ values from stream segments that are in the valley bottom of the trunk stream. We set a minimum drainage area to define a stream as $0.48 \mathrm{~km}^{2}$ (Roback et al., 2018). In our $k_{s n}^{*}$ ratio analysis, we have excluded confluences where the trunk valley at the confluence point has geometry that is indicative of erosion by direct glacial action (U-shaped valleys), confluences where the tributary channel was likely to have been glaciated in its headwaters at the LGM (and thus may have experienced GLOF erosion as well), and confluences where the trunk channel has extensive headwaters on the Tibetan Plateau. We excluded the last category because the extent of glaciation on the Tibetan Plateau is still debated and a wide range of possibilities may be realistic (Kirchner et al., 2011). If regions above 4200 meters on the plateau were potentially ice-free at the LGM, then our proxy for GLOF frequency (total drainage area above the LGM ELA) does not apply in these rivers. 
https://doi.org/10.5194/esurf-2021-54

Preprint. Discussion started: 3 August 2021

(c) Author(s) 2021. CC BY 4.0 License.

Equations 3 and 4 are derived from the detachment-limited stream power model (Howard, 1994), and a comparison of $k_{s n}^{*}$ between channels assumes that both erode according to this model. Incision by lake outburst floods is a vastly more efficient process than incision by runoff-driven floods (Cook et al., 2018), in that it can do more erosive work on lower gradient channels with less contributing drainage area, meaning $k_{s n}$ analysis could systematically underestimate incision in channels in which outburst flooding is an important geomorphic agent.

\subsection{Knickpoint Distribution}

For our analysis of knickpoint distribution, we used the "knickpointfinder" function in TopoToolbox to identify and inventory knickpoints in the study area (Schwanghart and Scherler, 2014). Tributaries included in the knickpoint inventory are 1st or 2nd order streams that drain into 4th or higher order trunk streams and are at least 690 meters ASL (see example river profiles in Supplement Figure 2). Similar to our $k_{s n}^{*}$ ratio analysis, we excluded tributaries to trunk streams that substantially drain the Tibetan Plateau since the extent of LGM glaciation on the plateau is much debated. We set a minimum relief of 20 meters as the threshold for inclusion, to minimize the possibility of false knickpoints arising from noise in the topographic data. Since knickpoints can arise from many different geologic processes, we conducted the knickpoint search on parts of the tributary network we assume to be most affected by potential geologically recent outburst floods in the trunk channel, within 2 kilometres of a trunk stream. We included all confluences between tributaries in the knickpoint search and trunk streams from which upstream drainage area above the ELA is reported.

\subsection{Adjusted normalized channel wideness index $\left(k_{w n}^{*}\right)$}

Most fluvial networks are characterized by a power-law increase in the width of channels as a function of contributing drainage area. This relationship is governed by many factors, including erosion rate, lithology, and climate, among others. Particularly in regions where extreme events can generate massive sediment inputs, channel width increases with aggradation (Schwanghart et al., 2016) while relative channel width decreases with increased unit stream power, where bedrock is readily exposed and channels may incise downward (Croissant et al., 2017). Dynamic channel width may thus illustrate channel response to tectonic or process-driven forcing. We can approach a width-area trend using an equation with the same form as slope-area, although the relationship between upstream drainage area and width is positive, so

$W=k_{w} A^{b}$

or considering a discharge estimate accounting for precipitation and evapotranspiration in place of drainage area,

$W=k_{w}^{*} A^{b^{*}}$

215 where $W$ is the channel width and $k_{w}$ is a channel wideness index analogous to $k_{s}$. By fixing a best-fit reference value for $b$, we can examine local variation in channel wideness in response to enhanced erosion by increased GLOF activity.

To investigate the influence of GLOFs on channel width patterns, we used Google Earth imagery to make 1,598 width measurements from rivers across our study area, spacing measurements roughly equally along river reaches (Supplemental 
https://doi.org/10.5194/esurf-2021-54

Preprint. Discussion started: 3 August 2021

(c) Author(s) 2021. CC BY 4.0 License.

Figure 1). We measured the widths of valley bottoms instead of the channels themselves, since the active channel can change in width rapidly with deposition from local landslides and subsequent evacuation of deposits. We determined the location of transitions from valley floors to hillslopes by observations of several features. Many valley bottoms have riparian vegetation that is visually distinct from vegetation on the hillslopes. In parts of the study area where valleys and hillslopes are developed for agriculture, farm terraces rapidly narrow where the hillslopes begin to steepen, offering a simple visual indication of the base of the hillslopes. Fluvial terraces are also visible in satellite imagery and aid in distinguishing active valley bottom from abandoned surfaces. We included terraces within $10 \mathrm{~m}$ of the elevation of the active channel in the valley bottom measurements, since a single outburst flood may incise enough to remobilize terrace material several meters above the active channel (Cook et al., 2018). Our assumption that the width of valley bottoms is analogous to the width of active channels is supported by the observed power law relationships between discharge and valley width in the field area.

While the width of the active channel itself can vary significantly over a short time, we expect the width of the valley floor should reflect longer-term trends given that the timescales inherent in significantly raising or lowering an entire valley floor (and thus widening or narrowing it) should be orders of magnitude longer than timescales governing the width of the channel (Ray and Srivastava, 2010). As in our $k_{s n}^{*}$ calculation, we use TRMM precipitation and GLEAM evapotranspiration data to estimate discharge, calculating a normalized channel wideness index as (Allen et al., 2013; Yanites et al., 2018):

$W=k_{w n}^{*} Q^{b_{r e f}^{*}}$

\subsection{Statistical Analyses}

Spearman rank correlation coefficients (Spearman's $\rho$ ) and P-values were calculated using the Matlab "corr" function with the "Spearman" parameter. The Spearman's $\rho$ is a nonparametric measure of the strength of association between two variables, specifically useful for testing for a monotonic relationship where the nature of that relationship is unknown (Spearman, 1987). We chose the Spearman's test since it was unclear what functional form the expected relationships among our variables should take. We also used two-sample Kolmogorov-Smirnov (K-S) tests, which compare the empirical distribution functions of two samples (Massey, 1951). K-S tests were conducted and P-values calculated using the Matlab "kstest2" function.

\section{Results}

\subsection{Steepness Ratios Between Tributaries and Trunk Streams}

Along the course of the major Himalayan rivers, the mainstems typically drain glaciated areas, while many of the tributaries do not. We compared channel steepness between these by calculating the ratio of tributary $k_{s n}^{*}$ to trunk stream $k_{s n}^{*}$ near where each tributary joins the mainstem (Figure 1B). Typically, unless a confluence coincides with the location of a lithologic contact, active deformation structure, or transient knickpoint, $k_{s n}^{*}$ values in a mainstem and its tributary measured very close to the confluence should be approximately equal. In many cases, we find that rivers with a greater proportion of upstream glaciated terrain have tributaries that are steeper near confluences (Figure 3). We interpret this steepening of tributaries as being a 
https://doi.org/10.5194/esurf-2021-54

Preprint. Discussion started: 3 August 2021

(c) Author(s) 2021. CC BY 4.0 License.

response to accelerated incision rates in the trunk streams driven by GLOFs. Repeated GLOFs occurring from the same source areas along the same flow paths will produce a persistent difference in erosion rate between erosionally less efficient tributaries and GLOF-dominated trunk streams. This difference would require the tributaries that lack glaciated terrain to steepen to keep pace with erosion of the mainstem, increasing the $k_{s n}^{*}$ ratio - as we observe.

One potential complication is that in small, very steep catchments, such as many of the tributaries examined in this study, debris flows can control channel geometry at drainage areas of up to several square kilometres (Dahlquist and West, 2019). Since channels incising due to debris flow action do not follow a power law relationship between slope and drainage area, the use of $k_{s n}^{*}$ as a simple uplift-incision proxy in these catchments is problematic (Stock and Dietrich, 2006). If debris flow erosion is indeed an important control on channel geometry along some of the 1st and 2nd order basins we studied, the steepening trend we observe in tributaries responding to more frequent GLOFs in the trunk channel may reflect steeper tributaries allowing for more frequent debris flows with longer runouts capable of doing more erosional work (Stock and Dietrich, 2006). Yet we argue that this additional erosional work still reflects steepness produced by incision of the main stem, i.e., via GLOF activity.

\subsection{Knickpoint distribution and GLOF erosion}

To verify whether patterns of knickpoints are consistent with GLOF incision being a prominent component of Himalayan erosion, we analysed the distribution of knickpoints on tributaries within 2 kilometres of 4th or higher order rivers (Supplemental Figure 1). In 3062 tributary channels, we found 5970 knickpoints with at least 20 meters of relief. We log-binned knickpoint counts and total knickpoint relief by the amount of upstream drainage area above the ELA in the trunk stream that each tributary joins (Figure 4). We then assessed the proportion of knickpoints that are found in tributaries to rivers without glaciated headwaters, and we compared this proportion to that of tributary confluences in general. We found that knickpoints are much less common in tributaries to rivers with no glaciated drainage area upstream (Figure 4). Only $\sim 18 \%$ of the knickpoints are found on tributaries to rivers without glaciated headwaters; in comparison, $30 \%$ of the tributaries analysed drain to rivers with no drainage area above the ELA. This effect is more pronounced when knickpoints are weighted by relief, with only $15 \%$ of the total knickpoint relief found on these tributaries to unglaciated rivers. In tributaries to substantially glaciated rivers, we find over-representation of the knickpoints, an effect that is accentuated when knickpoints are weighted by relief (Figure 4B).

The greater proportions of knickpoints and total knickpoint relief in the tributaries that drain into more glaciated channels support our conceptual model, wherein GLOF erosion creates knickpoints in tributaries at their confluences with the path of repeated outburst floods. These tributary knickpoints may stall at the confluences (Crosby et al., 2007; Goode and Burbank, 2009), or they may propagate upstream. By identifying knickpoints found up to 2 kilometres upstream from a potential GLOF path, we include both possibilities. We limit our analysis to the first 2 kilometres along the tributaries to minimize the possibility of crossing structural or lithologic gradients, risking the inclusion of knickpoints formed by other conditions.

Interestingly, in both $k_{s n}^{*}$ ratios and knickpoint prevalence, we observe a threshold for the formation of these features. Around $10 \mathrm{~km}^{2}$ of glaciated drainage area is required before the $k_{s n}^{*}$ ratios begin to increase (Figure 3). Similarly, knickpoint prevalence only increases where the trunk stream drains on the order of $10 \mathrm{~km}^{2}$ of above-ELA terrain, although data are relatively scarce for lower areas (only 364 of 5970 knickpoints and 185 of 3062 tributary channels drain to trunk streams with between $1-10^{7}$ 
https://doi.org/10.5194/esurf-2021-54

Preprint. Discussion started: 3 August 2021

(c) Author(s) 2021. CC BY 4.0 License.

$\mathrm{m}^{2}$ of above-ELA terrain in their basins). Considering the apparent threshold in both metrics, we speculate that an upstream area of glaciated terrain on the order of $10 \mathrm{~km}^{2}$ is required to produce recognizable outburst flood topography downstream in this region.

\subsection{Valley widths and the role of GLOFs in "clearing the pipeline" of sediment}

We expect that variation in valley floor width reflects the extent of alluviation. Wider valleys should have less frequent bedrock exposure, reflecting aggradation and slower incision. Valleys on GLOF paths should be systemically narrower than expected for a given discharge if GLOFs are clearing out sediment and driving rapid incision frequently enough to control river morphology.

Measurements of our valley width metric $k_{w n}^{*}$ corroborate our inferences from $k_{s n}^{*}$ and knickpoint occurrence: we find distinct trends in the relationship between valley width and discharge, with rivers that have upstream glaciers being narrower at lower discharges than rivers without glaciated headwaters (Figure 5A). Moreover, among rivers that do include glaciated terrain, valleys with more glaciated drainage area tend to have lower $k_{w n}^{*}$ (Figure 5D). These observations suggest that GLOFs keep valley bottoms free of coarse sediment that broadens valleys and armors the bedrock channel bed against erosion. In other words, more frequent GLOFs "clear the pipeline", preventing clogging and allowing valleys to remain narrow. This is not simply a binary relationship, i.e., we do not see valleys with upstream glaciers relatively free of alluvium versus those without glaciers containing substantial fill, but rather find that the valley width appears to depend on the frequency or magnitude of the floods as inferred from upstream glaciated area (Figure 5D).

\subsection{Influence of uplift and erosion on geomorphic metrics}

Several other differences across the central Himalaya of Nepal are expected to influence river valley morphology, most notably the pronounced south-to-north increase in uplift and denudation rates. Most of the differences we document as being related to GLOF activity are between different N-S trending river valleys, i.e., between rivers with glaciated headwater versus those without, so we do not expect that differences in uplift and erosion rates are a major confounding factor in our analysis. Nonetheless, to test whether and how differences in uplift and erosion might affect the metrics we have used, we examined a subset of basins in the study area which have published estimates of uplift rate derived from river profile analysis (Lavé and Avouac, 2001) and Beryllium-10-derived basin-averaged denudation rates (Godard et al., 2014). These basins contain no or minimal drainage area above the LGM ELA, ruling out the possibility of GLOFs as an important erosion mechanism within these basins and thus allowing us to test for the role of other factors. These basins vary by more than an order of magnitude in uplift and erosion rates, capturing much of the variation found in our study area as a whole (Supplementary Table 1).

For the basins shown in Figure 6, we examined $k_{s n}^{*}$ ratios between tributaries and trunk streams by the same methods as we used for the whole study area. Figure 7 shows $k_{s n}^{*}$ ratios at confluences plotted against uplift and denudation rates. We find no relationship between denudation rate and $k_{s n}^{*}$ ratios. While there is a weak association between basin uplift rate and $k_{s n}^{*}$ ratios $(P<0.05)$, our interpretation is that this is unlikely to account for the trend we observe in our results shown in Figure 3.

315 We also took additional valley floor width measurements in the studied basins to test for the effect of denudation and uplift rates on valley width versus discharge trends. We fit width-discharge trends for all basins using Equation 6 (results shown in 
https://doi.org/10.5194/esurf-2021-54

Preprint. Discussion started: 3 August 2021

(c) Author(s) 2021. CC BY 4.0 License.

Figure 8). We calculated $k_{w n}^{*}$ for each basin, using a best-fit $b_{r e f}^{*}$ of 0.3195 . We found no correlation between width-discharge trends and uplift and erosion rates, allowing us to rule out these factors as major complications for our interpretations.

Altogether, we observe no coherent relationships between $k_{s n}^{*}$ ratios or $k_{w n}^{*}$ values and either uplift or denudation rate, suggesting that variations in these factors across the study region are not likely to explain the correlations we observe between our metrics of river morphology and the extent of glaciated headwater area. While our analysis based on spatial correlations cannot conclusively rule out other complicating lithologic, tectonic, and climatic factors, we have no reason to expect these to produce the trends we observe.

\section{Discussion}

\subsection{The Physiographic Transition: Shift from "top down" to "bottom up" erosion}

Altogether, our analysis suggests that rivers in the central Himalaya bear characteristic signatures of erosion by glacial outburst floods, suggesting that these events are an important but largely under-recognized mechanism of regional incision. Yet GLOFs can only be effective so far downstream. Cook et al. (2018) studied two major GLOFs in the Bhote Khosi valley, occurring in 1981 and 2016, and identified the location of rollover points along the downstream river profile where GLOF discharges attenuated to the point that a monsoon flood with the same recurrence would have greater discharge. These points lie very near the prominent physiographic transition (PT) that separates the precipitous High Himalaya from the gentler Middle Hills to the south (Figure 1A).

The abruptness of the PT reflects the topographic response to a steep gradient in uplift rate and is associated with a pronounced increase in erosion rates from south to north (Burbank et al., 2003; Wobus et al., 2006b; Godard et al., 2014). Over much of its length, the PT also represents a contact between the low-grade Lesser Himalayan Sequence and high-grade High Himalayan Sequence, although in our study area the Kathmandu Nappe juxtaposes High Himalayan rocks into the Lesser Himalaya physiographic region, with no substantial effect on the topography (Gansser, 1964). Intriguingly, we find evidence for weakening of the influence of GLOFs on channel geometry when we look at tributary steepness relative to trunk streams above versus below the PT. The relationship between drainage area above the ELA and steepness ratio is no longer evident for confluences below the elevation of the 1981 GLOF rollover point (Figure 3B). These regions of the landscape that are only weakly affected by GLOF erosion would also explain why the highest above-ELA drainage area confluences have anomalously low $k_{s n}^{*}$ ratios in Figure 3A. It thus appears that the PT may demarcate a shift in erosional process domain, representing the position above which "top-down" GLOF-driven incision is prominent enough to maintain a persistent topographic signature.

\subsection{Implications for development of fluvial hanging valleys}

345 "Fluvial hanging valleys" - steepened tributary reaches near their confluence with mainstem rivers — have been identified previously in the Himalaya and elsewhere. While often considered enigmatic features, their persistence in the landscape has been explained by erosional mechanics that produce lower erosional efficiency in steeper river reaches with low sediment 
https://doi.org/10.5194/esurf-2021-54

Preprint. Discussion started: 3 August 2021

(c) Author(s) 2021. CC BY 4.0 License.

flux (Crosby et al., 2007; Goode and Burbank, 2009). Not all of the steepened zones near confluences that we have identified represent true hanging valley geometry, but our analyses of both $k_{s n}^{*}$ ratios and knickpoint prevalence suggest that repeated outburst floods in a trunk stream may, under the correct conditions, control mainstem river incision and generate fluvial hanging valleys. In this case, we explain the formation of these features as resulting from the tributary steepening needed to keep pace with the GLOF-driven incision of the mainstem, producing persistent knickpoints near the location where tributaries enter trunk channels with upstream glaciation (Figures 2D-E). We thus propose a connection between the formation of fluvial hanging valleys and upstream glaciation that leads to GLOF-driven erosion in the mainstem.

\subsection{Landscape Evolution from the Top Down}

A simple end-member model of fluvial incision involves the formation of a knickpoint, or localized steepening, in response to uplift which manifests as a drop in a river's base level (Whipple and Tucker, 1999) (Figures 2A-C). In this model, increased steepness causes localized increases in erosion, and the knickpoint propagates upstream. Complexity in this process of incision and knickpoint propagation has been increasingly recognized: channels dominated by bedload abrasion may have knickpoint retreat rates that are decoupled from overall incision rates (Jansen et al., 2011; Wilson et al., 2013), and knickpoints may be smoothed out over years to decades in the presence of copious bedload and sufficient discharge (Cook et al., 2013).

Our analysis of Himalayan river channels suggests that "top down" incision driven by GLOFs may be another important factor in driving erosion and determining channel morphology in glaciated mountain belts. Based on relationships we have documented between the area of glaciated headwaters, tributary channel steepness, knickpoint occurrence, and valley widths, we propose that incision processes in the High Himalayan rivers of central Nepal are influenced in important ways from above, by outburst floods from the headwaters of the trunk streams. In this case, a critical controlling factor for the geometry of tributaries is their steepening in response to GLOF erosion.

If this process is as pervasive elsewhere as our data suggest it may be in the central Himalaya, it would have significant implications for the evolution of orogens in response to tectonic and climatic forcing. In particular, an important role for GLOF erosion, such as that we have identified, implies that the relationship between tectonics and erosion would be modulated by the migration of the ELA. If uplift pushes terrain above the ELA, it could create new glaciers and glacial lakes that, in turn, accelerate GLOF-driven incision. This feedback, in tandem with the propagation of knickpoints from below, could link uplift and erosion rates in ways not captured in current models of landscape evolution. Alongside the effect of tectonics, climatic shifts can drive the ELA to higher or lower elevations, shifting dominant process domains and their signature relief structures to higher or lower elevations. Studies of landscape evolution and interpretations of river channel morphology and network geometry in mountainous environments should consider the influence of outburst floods as regional drivers of erosion, even where glaciers are no longer present. Altogether, our results suggest a rethinking is warranted of classic models of mountain river system evolution, to consider the role of glacial outburst floods as regional controls on erosion. 
https://doi.org/10.5194/esurf-2021-54

Preprint. Discussion started: 3 August 2021

(c) Author(s) 2021. CC BY 4.0 License.

\section{Conclusions}

We found several lines of topographic evidence consistent with GLOF-controlled incision in rivers with glaciated headwaters in the Nepal Himalaya. Tributaries to GLOF-prone rivers form fluvial hanging valleys where increasing extent of upstream glaciation in the trunk stream (and thus increasing GLOF frequency) is manifest as increased steepness in the tributaries. We also found that the knickpoints are more numerous on tributaries to trunk stream with more glaciated terrain upstream, which further evidences the steepening response that highly efficiently eroding outburst flood-dominated channels stimulate in their tributaries.

Additionally, rivers with glaciated headwaters have systematically narrower valleys than unglaciated rivers, indicating that GLOFs effectively sweep coarse alluvium from valleys and expose bedrock to erosion. This effect is increasingly prominent with more upstream glaciation. Alongside evidence that outburst floods alone can mobilize the large boulders that frequently armor channels in major Himalayan rivers, this evidence suggests that GLOFs may be a dominant erosional mechanism in these rivers. Our results point to a top-down model for valley incision in the Himalaya, in which erosion is coupled to tectonics by uplift driving terrain above the ELA, expanding the reach of GLOFs, as opposed to (or in addition to) tectonically generated knickpoints propagating throughout Himalayan catchments from base level. GLOF-driven erosion may be important in other glaciated mountain ranges, appears to be independent of uplift and erosion rates, and should be considered in erosion models for such landscapes.

Data availability. Upon publication, the datasets generated and analysed during the current study will be made available in the Hydroshare repository, http://www.hydroshare.org/resource/2883cfeebb3a43f2b9a1b222e2cfff29

Author contributions. MPD and AJW conceived the study. MPD performed the analyses. MPD and AJW wrote the manuscript.

Competing interests. The authors declare that they have no conflict of interest.

Acknowledgements. We thank Kristen Cook, John Jansen, Jens Turowski, Georg Veh, and Missy Eppes for helpful discussions. We also thank William Medwedeff for the photograph used in Figure 2. This work was supported by NSF award EAR-1640894. 
https://doi.org/10.5194/esurf-2021-54

Preprint. Discussion started: 3 August 2021

(c) Author(s) 2021. CC BY 4.0 License.

\section{References}

Allen, G. H., Barnes, J. B., Pavelsky, T. M., and Kirby, E.: Lithologic and tectonic controls on bedrock channel form at the northwest Himalayan front: BEDROCK CHANNEL FORM, MOHAND, INDIA, Journal of Geophysical Research: Earth Surface, 118, 1806-1825, https://doi.org/10.1002/jgrf.20113, 2013.

Asahi, K.: Equilibrium-line altitudes of the present and Last Glacial Maximum in the eastern Nepal Himalayas and their implications for SW monsoon climate, Quaternary International, 212, 26-34, https://doi.org/10.1016/j.quaint.2008.08.004, 2010.

Baynes, E. R., Attal, M., Dugmore, A. J., Kirstein, L. A., and Whaler, K. A.: Catastrophic impact of extreme flood events on the morphology and evolution of the lower Jökulsá á Fjöllum (northeast Iceland) during the Holocene, Geomorphology, 250, 422-436, https://doi.org/10.1016/j.geomorph.2015.05.009, 2015.

Bookhagen, B.: High Resolution Spatiotemporal Distribution of Rainfall Seasonality and Extreme Events Based on a 12-year TRMM Time Series, 2013.

Brozović, N., Burbank, D. W., and Meigs, A. J.: Climatic Limits on Landscape Development in the Northwestern Himalaya, Science, 276, 571, https://doi.org/10.1126/science.276.5312.571, 1997.

Burbank, D. W., Blythe, A. E., Putkonen, J., Pratt-Sitaula, B., Gabet, E., Oskin, M., Barros, A., and Ojha, T. P.: Decoupling of erosion and precipitation in the Himalayas, Nature, 426, 652-655, https://doi.org/10.1038/nature02187, 2003.

Cenderelli, D. A. and Wohl, E. E.: Flow hydraulics and geomorphic effects of glacial-lake outburst floods in the Mount Everest region, Nepal, Earth Surface Processes and Landforms, 28, 385-407, https://doi.org/10.1002/esp.448, 2003.

Cook, K. L., Turowski, J. M., and Hovius, N.: A demonstration of the importance of bedload transport for fluvial bedrock erosion and knickpoint propagation: BEDLOAD TRANSPORT AND FLUVIAL INCISION, Earth Surface Processes and Landforms, 38, 683-695, https://doi.org/10.1002/esp.3313, 2013.

Cook, K. L., Andermann, C., Gimbert, F., Adhikari, B. R., and Hovius, N.: Glacial lake outburst floods as drivers of fluvial erosion in the Himalaya, p. 6, 2018.

Croissant, T., Lague, D., Steer, P., and Davy, P.: Rapid post-seismic landslide evacuation boosted by dynamic river width, Nature Geoscience, 10, 680-684, https://doi.org/10.1038/ngeo3005, 2017.

Crosby, B. T., Whipple, K. X., Gasparini, N. M., and Wobus, C. W.: Formation of fluvial hanging valleys: Theory and simulation, Journal of Geophysical Research, 112, https://doi.org/10.1029/2006JF000566, 2007.

Cunningham, M. T., Stark, C. P., Kaplan, M. R., and Schaefer, J. M.: Glacial limitation of tropical mountain height, Earth Surface Dynamics, 7, 147-169, https://doi.org/10.5194/esurf-7-147-2019, 2019.

Dahlquist, M. P. and West, A. J.: Initiation and Runout of Post-Seismic Debris Flows: Insights From the 2015 Gorkha Earthquake, Geophysical Research Letters, 46, 9658-9668, https://doi.org/10.1029/2019GL083548, 2019.

Davis, W. M.: Glacial Erosion in France, Switzerland and Norway, Proceedings of the Boston Society of Natural History, 29, 273-321, 1900.

DiBiase, R. A. and Whipple, K. X.: The influence of erosion thresholds and runoff variability on the relationships among topography, climate, and erosion rate, Journal of Geophysical Research, 116, https://doi.org/10.1029/2011JF002095, 2011.

Egholm, D. L., Nielsen, S. B., Pedersen, V. K., and Lesemann, J.-E.: Glacial effects limiting mountain height, Nature, 460, 884-887, https://doi.org/10.1038/nature08263, 2009.

Finnegan, N. J., Roe, G., Montgomery, D. R., and Hallet, B.: Controls on the channel width of rivers: Implications for modeling fluvial incision of bedrock, Geology, 33, 229, https://doi.org/10.1130/G21171.1, 2005. 
https://doi.org/10.5194/esurf-2021-54

Preprint. Discussion started: 3 August 2021

(c) Author(s) 2021. CC BY 4.0 License.

Finnegan, N. J., Schumer, R., and Finnegan, S.: A signature of transience in bedrock river incision rates over timescales of 104-107 years, Nature, 505, 391-394, https://doi.org/10.1038/nature12913, 2014.

Fischer, M., Korup, O., Veh, G., and Walz, A.: Controls of outbursts of moraine-dammed lakes in the greaterHimalayan region, preprint, Glaciers/Natural Hazards, https://doi.org/10.5194/tc-2020-327, 2020.

Flint, J. J.: Stream gradient as a function of order, magnitude, and discharge, Water Resources Research, 10, 969-973, https://doi.org/10.1029/WR010i005p00969, 1974.

Forte, A. M. and Whipple, K. X.: Short communication: The Topographic Analysis Kit (TAK) for TopoToolbox, Earth Surface Dynamics, 7 , 87-95, https://doi.org/10.5194/esurf-7-87-2019, 2019.

Gansser, A.: Geology of the Himalayas, Interscience Publishers, London, 1964.

Gardner, T. W., Jorgensen, D. W., Shuman, C., and Lemieux, R., C.: Geomorphic and tectonic process rates: Effects of measured time interval, Geology, 15, 259-261, 1987.

Gasparini, N. M. and Whipple, K. X.: Diagnosing climatic and tectonic controls on topography: Eastern flank of the northern Bolivian Andes, Lithosphere, 6, 230-250, https://doi.org/10.1130/L322.1, 2014.

Godard, V., Bourles, D. L., Spinabella, F., Burbank, D. W., Bookhagen, B., Fisher, G. B., Moulin, A., and Leanni, L.: Dominance of tectonics over climate in Himalayan denudation, Geology, 42, 243-246, https://doi.org/10.1130/G35342.1, 2014.

Goode, J. K. and Burbank, D. W.: Numerical study of degradation of fluvial hanging valleys due to climate change, Journal of Geophysical Research, 114, https://doi.org/10.1029/2007JF000965, 2009.

Haeberli, W.: Frequency and Characteristics of Glacier Floods in the Swiss Alps, Annals of Glaciology, 4, 85-90, https://doi.org/https://doi.org/10.3189/S0260305500005280, 1983.

Hewitt, K.: Catastrophic landslides and their effects on the Upper Indus streams, Karakoram Himalaya, northern Pakistan, Geomorphology, 26, 47-80, https://doi.org/10.1016/S0169-555X(98)00051-8, 1998.

Hilton, R. G. and West, A. J.: Mountains, erosion and the carbon cycle, Nature Reviews Earth \& Environment, 1, 284-299, https://doi.org/10.1038/s43017-020-0058-6, 2020.

Howard, A. D.: A detachment-limited model of drainage basin evolution, Water Resources Research, 30, 2261-2285, https://doi.org/10.1029/94WR00757, 1994.

Huber, M. L., Lupker, M., Gallen, S. F., Christl, M., and Gajurel, A. P.: Timing of exotic, far-travelled boulder emplacement and paleooutburst flooding in the central Himalaya, preprint, Physical: Geomorphology (including all aspects of fluvial, coastal, aeolian, hillslope and glacial geomorphology), https://doi.org/10.5194/esurf-2020-17, 2020.

Jacquet, J., McCoy, S. W., McGrath, D., Nimick, D. A., Fahey, M., O’kuinghttons, J., Friesen, B. A., and Leidich, J.: Hydrologic and geomorphic changes resulting from episodic glacial lake outburst floods: Rio Colonia, Patagonia, Chile, Geophysical Research Letters, 44, 854-864, https://doi.org/10.1002/2016GL071374, 2017.

Jansen, J. D., Fabel, D., Bishop, P., Xu, S., Schnabel, C., and Codilean, A. T.: Does decreasing paraglacial sediment supply slow knickpoint retreat?, Geology, 39, 543-546, https://doi.org/10.1130/G32018.1, 2011.

Kirby, E. and Whipple, K.: Quantifying differential rock-uplift rates via stream profile analysis, Geology, 29, 415, https://doi.org/10.1130/0091-7613(2001)029<0415:QDRURV>2.0.CO;2, 2001.

Kirchner, J. W., Finkel, R. C., Riebe, C. S., Granger, D. E., Clayton, J. L., King, J. G., and Megahan, W. F.: Mountain erosion over 10 yr, 10 k.y., and 10 m.y. time scales, Geology, 29, 591, https://doi.org/10.1130/0091-7613(2001)029<0591:MEOYKY>2.0.CO;2, 2001. 
https://doi.org/10.5194/esurf-2021-54

Preprint. Discussion started: 3 August 2021

(c) Author(s) 2021. CC BY 4.0 License.

Kirchner, N., Greve, R., Stroeven, A. P., and Heyman, J.: Paleoglaciological reconstructions for the Tibetan Plateau during the last glacial cycle: evaluating numerical ice sheet simulations driven by GCM-ensembles, Quaternary Science Reviews, 30, 248-267, https://doi.org/10.1016/j.quascirev.2010.11.006, 2011.

Korup, O. and Tweed, F.: Ice, moraine, and landslide dams in mountainous terrain, Quaternary Science Reviews, 26, 3406-3422, https://doi.org/10.1016/j.quascirev.2007.10.012, 2007.

Korup, O., Montgomery, D. R., and Hewitt, K.: Glacier and landslide feedbacks to topographic relief in the Himalayan syntaxes, Proceedings of the National Academy of Sciences, 107, 5317-5322, https://doi.org/10.1073/pnas.0907531107, 2010.

Lague, D., Hovius, N., and Davy, P.: Discharge, discharge variability, and the bedrock channel profile: DISCHARGE VARIABILITY AND CHANNEL PROFILE, Journal of Geophysical Research: Earth Surface, 110, n/a-n/a, https://doi.org/10.1029/2004JF000259, 2005.

Lang, K. A., Huntington, K. W., and Montgomery, D. R.: Erosion of the Tsangpo Gorge by megafloods, Eastern Himalaya, Geology, 41, 1003-1006, https://doi.org/10.1130/G34693.1, 2013.

Larsen, I. J. and Montgomery, D. R.: Landslide erosion coupled to tectonics and river incision, Nature Geoscience, 5, 468-473, https://doi.org/10.1038/ngeo1479, 2012.

Lavé, J. and Avouac, J. P.: Fluvial incision and tectonic uplift across the Himalayas of central Nepal, Journal of Geophysical Research: Solid Earth, 106, 26 561-26 591, https://doi.org/10.1029/2001JB000359, 2001.

Lutz, A. F., Immerzeel, W. W., Shrestha, A. B., and Bierkens, M. F. P.: Consistent increase in High Asia's runoff due to increasing glacier melt and precipitation, Nature Climate Change, 4, 587-592, https://doi.org/10.1038/nclimate2237, 2014.

Martens, B., Miralles, D. G., Lievens, H., van der Schalie, R., de Jeu, R. A. M., Fernández-Prieto, D., Beck, H. E., Dorigo, W. A., and Verhoest, N. E. C.: GLEAM v3: satellite-based land evaporation and root-zone soil moisture, Geoscientific Model Development, 10, 1903-1925, https://doi.org/10.5194/gmd-10-1903-2017, 2017.

495 Mason, K.: Indus floods and Shyok glaciers, The Himalayan Journal, 1, 10-29, 1929.

Massey, F. J.: The Kolmogorov-Smirnov Test for Goodness of Fit, Journal of the American Statistical Association, 46, 68-78, 1951.

Montgomery, D. R. and Foufoula-Georgiou, E.: Channel network source representation using digital elevation models, Water Resources Research, 29, 3925-3934, https://doi.org/10.1029/93WR02463, 1993.

Montgomery, D. R., Hallet, B., Yuping, L., Finnegan, N., Anders, A., Gillespie, A., and Greenberg, H. M.: Evidence for Holocene megafloods down the tsangpo River gorge, Southeastern Tibet, Quaternary Research, 62, 201-207, https://doi.org/10.1016/j.yqres.2004.06.008, 2004.

Pickering, J., Diamond, M., Goodbred, S., Grall, C., Martin, J., Palamenghi, L., Paola, C., Schwenk, T., Sincavage, R., and Spieß, V.: Impact of glacial-lake paleofloods on valley development since glacial termination II: A conundrum of hydrology and scale for the lowstand Brahmaputra-Jamuna paleovalley system, GSA Bulletin, 131, 58-70, https://doi.org/10.1130/B31941.1, 2019.

Prasicek, G., Herman, F., Robl, J., and Braun, J.: Glacial Steady State Topography Controlled by the Coupled Influence of Tectonics and Climate, Journal of Geophysical Research: Earth Surface, 123, 1344-1362, https://doi.org/10.1029/2017JF004559, 2018.

Ray, Y. and Srivastava, P.: Widespread aggradation in the mountainous catchment of the Alaknanda-Ganga River System: timescales and implications to Hinterland-foreland relationships, Quaternary Science Reviews, 29, 2238-2260, https://doi.org/10.1016/j.quascirev.2010.05.023, 2010.

Raymo, M. E. and Ruddiman, W. F.: Tectonic forcing of late Cenozoic climate, Nature, 359, 117-122, https://doi.org/10.1038/359117a0, 1992. 
https://doi.org/10.5194/esurf-2021-54

Preprint. Discussion started: 3 August 2021

(c) Author(s) 2021. CC BY 4.0 License.

Roback, K., Clark, M. K., West, A. J., Zekkos, D., Li, G., Gallen, S. F., Chamlagain, D., and Godt, J. W.: The size, distribution, and mobility of landslides caused by the $2015 \mathrm{M}$ w 7.8 Gorkha earthquake, Nepal, Geomorphology, 301, 121-138, https://doi.org/10.1016/j.geomorph.2017.01.030, 2018.

Roe, G. H., Montgomery, D. R., and Hallet, B.: Orographic precipitation and the relief of mountain ranges: OROGRAPHIC PRECIPITATION AND RELIEF, Journal of Geophysical Research: Solid Earth, 108, https://doi.org/10.1029/2001JB001521, 2003.

Scherler, D., Munack, H., Mey, J., Eugster, P., Wittmann, H., Codilean, A. T., Kubik, P., and Strecker, M. R.: Ice dams, outburst floods, and glacial incision at the western margin of the Tibetan Plateau: A >100 k.y. chronology from the Shyok Valley, Karakoram, Geological Society of America Bulletin, 126, 738-758, https://doi.org/10.1130/B30942.1, 2014.

Schwanghart, W. and Scherler, D.: Short Communication: TopoToolbox 2 - MATLAB-based software for topographic analysis and modeling in Earth surface sciences, Earth Surface Dynamics, 2, 1-7, https://doi.org/10.5194/esurf-2-1-2014, 2014.

Schwanghart, W., Bernhardt, A., Stolle, A., Hoelzmann, P., Adhikari, B. R., Andermann, C., Tofelde, S., Merchel, S., Rugel, G., Fort, M., and Korup, O.: Repeated catastrophic valley infill following medieval earthquakes in the Nepal Himalaya, Science, 351, 147-150, https://doi.org/10.1126/science.aac9865, 2016.

Sklar, L. S. and Dietrich, W. E.: Sediment and rock strength controls on river incision into bedrock, Geology, 29, 1087, https://doi.org/10.1130/0091-7613(2001)029<1087:SARSCO>2.0.CO;2, 2001.

Sklar, L. S. and Dietrich, W. E.: The role of sediment in controlling steady-state bedrock channel slope: Implications of the saltation-abrasion incision model, Geomorphology, 82, 58-83, https://doi.org/10.1016/j.geomorph.2005.08.019, 2006.

Snyder, N. P., Whipple, K. X., Tucker, G. E., and Merritts, D. J.: Importance of a stochastic distribution of floods and erosion thresholds in the bedrock river incision problem: FLOODS AND THRESHOLDS IN RIVER INCISION, Journal of Geophysical Research: Solid Earth, 108, https://doi.org/10.1029/2001JB001655, 2003.

Spearman, C.: The Proof and Measurement of Association between Two Things, The American Journal of Psychology, 100, 441-471, 1987.

Steer, P., Simoes, M., Cattin, R., and Shyu, J. B. H.: Erosion influences the seismicity of active thrust faults, Nature Communications, 5 , 5564, https://doi.org/10.1038/ncomms6564, 2014.

Stock, J. D. and Dietrich, W. E.: Erosion of steepland valleys by debris flows, Geological Society of America Bulletin, 118, 1125-1148, 2006.

Thomson, S. N., Brandon, M. T., Tomkin, J. H., Reiners, P. W., Vásquez, C., and Wilson, N. J.: Glaciation as a destructive and constructive control on mountain building, Nature, 467, 313-317, https://doi.org/10.1038/nature09365, 2010.

Turowski, J. M., Yager, E. M., Badoux, A., Rickenmann, D., and Molnar, P.: The impact of exceptional events on erosion, bedload transport and channel stability in a step-pool channel, Earth Surface Processes and Landforms, 34, 1661-1673, https://doi.org/10.1002/esp.1855, 2009.

Veh, G., Korup, O., von Specht, S., Roessner, S., and Walz, A.: Unchanged frequency of moraine-dammed glacial lake outburst floods in the Himalaya, Nature Climate Change, 9, 379-383, https://doi.org/10.1038/s41558-019-0437-5, 2019.

Veh, G., Korup, O., and Walz, A.: Hazard from Himalayan glacier lake outburst floods, Proceedings of the National Academy of Sciences, 117, 907-912, https://doi.org/10.1073/pnas.1914898117, 2020.

545 Whipple, K. X. and Tucker, G. E.: Dynamics of the stream-power river incision model: Implications for height limits of mountain ranges, landscape response timescales, and research needs, Journal of Geophysical Research: Solid Earth, 104, 17 661-17674, https://doi.org/10.1029/1999JB900120, 1999.

Whittaker, A. C.: How do landscapes record tectonics and climate?, Lithosphere, 4, 160-164, https://doi.org/10.1130/RF.L003.1, 2012. 
https://doi.org/10.5194/esurf-2021-54

Preprint. Discussion started: 3 August 2021

(c) Author(s) 2021. CC BY 4.0 License.

Willett, S. D. and Brandon, M. T.: On steady states in mountain belts, Geology, 30, 175, https://doi.org/10.1130/00917613(2002)030<0175:OSSIMB>2.0.CO;2, 2002.

Wilson, A., Hovius, N., and Turowski, J. M.: Upstream-facing convex surfaces: Bedrock bedforms produced by fluvial bedload abrasion, Geomorphology, 180-181, 187-204, https://doi.org/10.1016/j.geomorph.2012.10.010, 2013.

Wobus, C., Whipple, K. X., Kirby, E., Snyder, N., Johnson, J., Spyropolou, K., Crosby, B., and Sheehan, D.: Tectonics from topography: Procedures, promise, and pitfalls, in: Special Paper 398: Tectonics, Climate, and Landscape Evolution, vol. 398, pp. 55-74, Geological Society of America, https://doi.org/10.1130/2006.2398(04), 2006a.

Wobus, C. W., Whipple, K. X., and Hodges, K. V.: Neotectonics of the central Nepalese Himalaya: Constraints from geomorphology, detrital ${ }^{40} \mathrm{Ar} /{ }^{39}$ Ar thermochronology, and thermal modeling: NEOTECTONICS OF CENTRAL NEPAL, Tectonics, 25, n/a-n/a, https://doi.org/10.1029/2005TC001935, 2006b.

$\mathrm{Xu}$, D.: Characteristics of debris flow caused by outburst of glacial lake in Boqu river, Xizang, China, 1981, GeoJournal, 17, https://doi.org/10.1007/BF00209443, 1988.

Yanites, B. J.: The Dynamics of Channel Slope, Width, and Sediment in Actively Eroding Bedrock River Systems, Journal of Geophysical Research: Earth Surface, 123, 1504-1527, https://doi.org/10.1029/2017JF004405, 2018.

Yanites, B. J., Mitchell, N. A., Bregy, J. C., Carlson, G. A., Cataldo, K., Holahan, M., Johnston, G. H., Nelson, A., Valenza, J., and Wanker, M.: Landslides control the spatial and temporal variation of channel width in southern Taiwan: Implications for landscape evolution and cascading hazards in steep, tectonically active landscapes: Variation in channel morphology controlled by landslides in s. Taiwan, Earth Surface Processes and Landforms, 43, 1782-1797, https://doi.org/10.1002/esp.4353, 2018. 

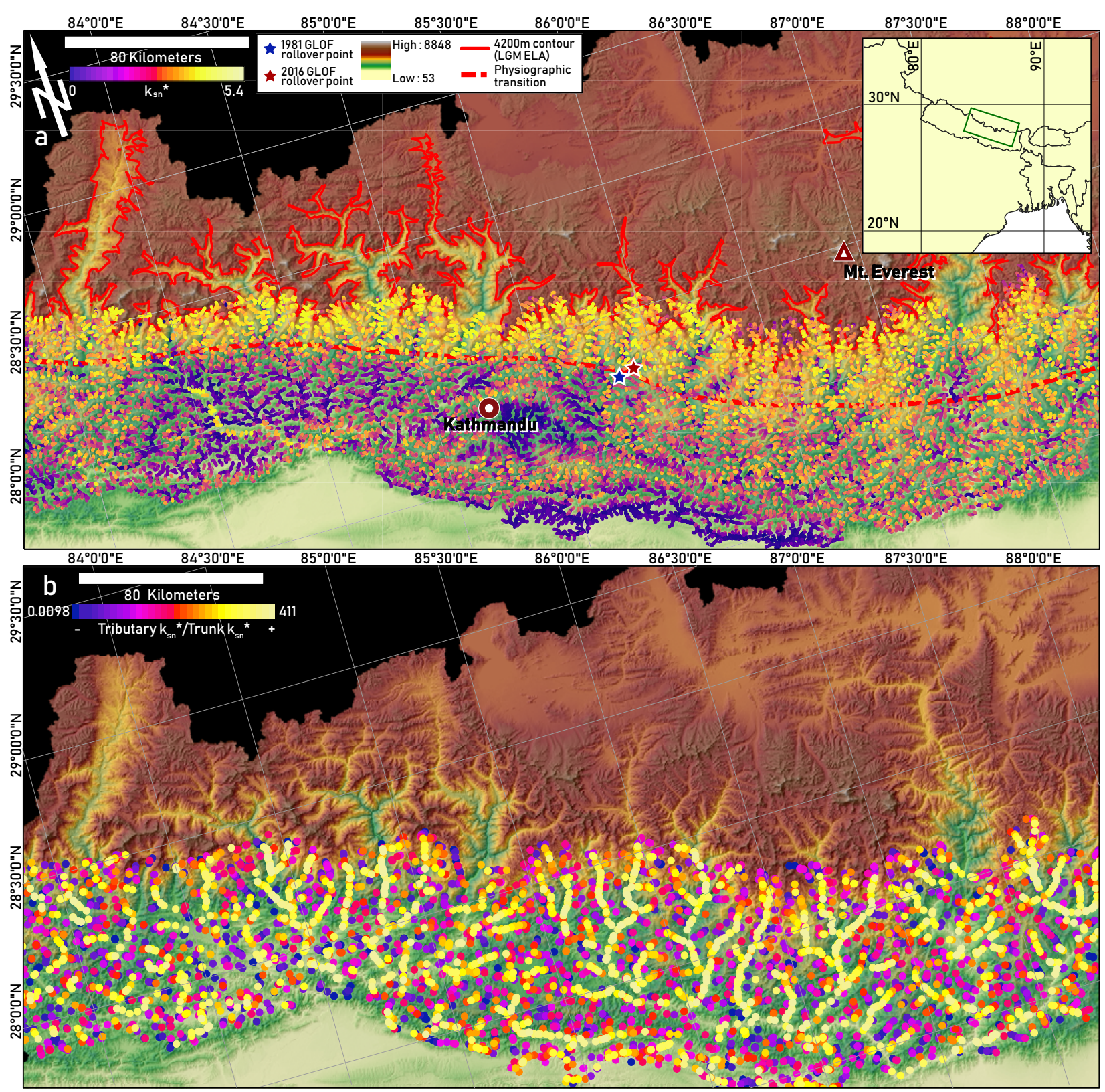

Figure 1. (a) Overview map of the study area, showing equilibrium line altitude at the Last Glacial Maximum (LGM ELA) along with other points of interest. $k_{s n}^{*}$ values are overlain on river network for elevations below LGM ELA and were calculated only where direct glacial action did not appear to be a major erosion mechanism. (b) $k_{s n}^{*}$ ratios at confluences included in this study, where Strahler order 1 and 2 tributaries enter order 3 or higher trunk streams. Markers are placed at the confluence where the $k_{s n}^{*}$ ratio was measured. 


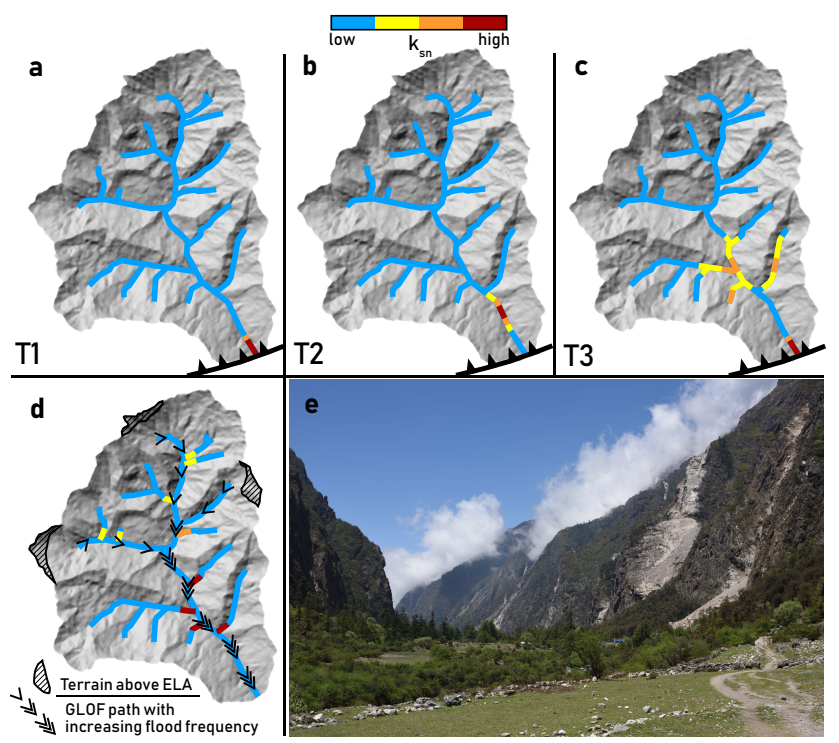

Figure 2. (a) Schematic of predicted $k_{s n}$ patterns arising from erosion driven by upstream knickpoint migration resulting from base level fall, including knickpoint diffusion described in alluvial and bedrock-alluvial channels (Rosenbloom and Anderson, 1994). (a-c) represent time steps showing the evolution of $k_{s n}$ patterns following a base level fall initiating at the thrust fault at the outlet of the catchment (T1 to T3 reflects temporal progression). In 1c, a second base level fall has initiated. (d) Schematic of steady state $k_{s n}$ patterns we hypothesize to arise from erosion driven by GLOFs originating from the high-elevation regions shown as terrain above ELA. Our aim in illustrating the simple scenario shown in panels a-c is not to suggest it as a plausible representation of the tectonic geomorphology of the Himalaya, but instead to contrast the end-member expectations from erosion purely driven by changes in base level versus the conceptual model we propose for glacial lake outburst flood (GLOF)-driven erosion, in panel d - while recognizing that actual erosion in Himalayan river valleys will involve an collaboration between these end-member scenarios. (e) Photograph from Langtang Valley, Nepal, showing steep inner valley walls and steep tributary catchments entering the trunk valley $\sim 1$ kilometer below the lowest identified glacial surfaces. Photo location is $28.200^{\circ} \mathrm{N}$, $85.460^{\circ} \mathrm{E}$. 


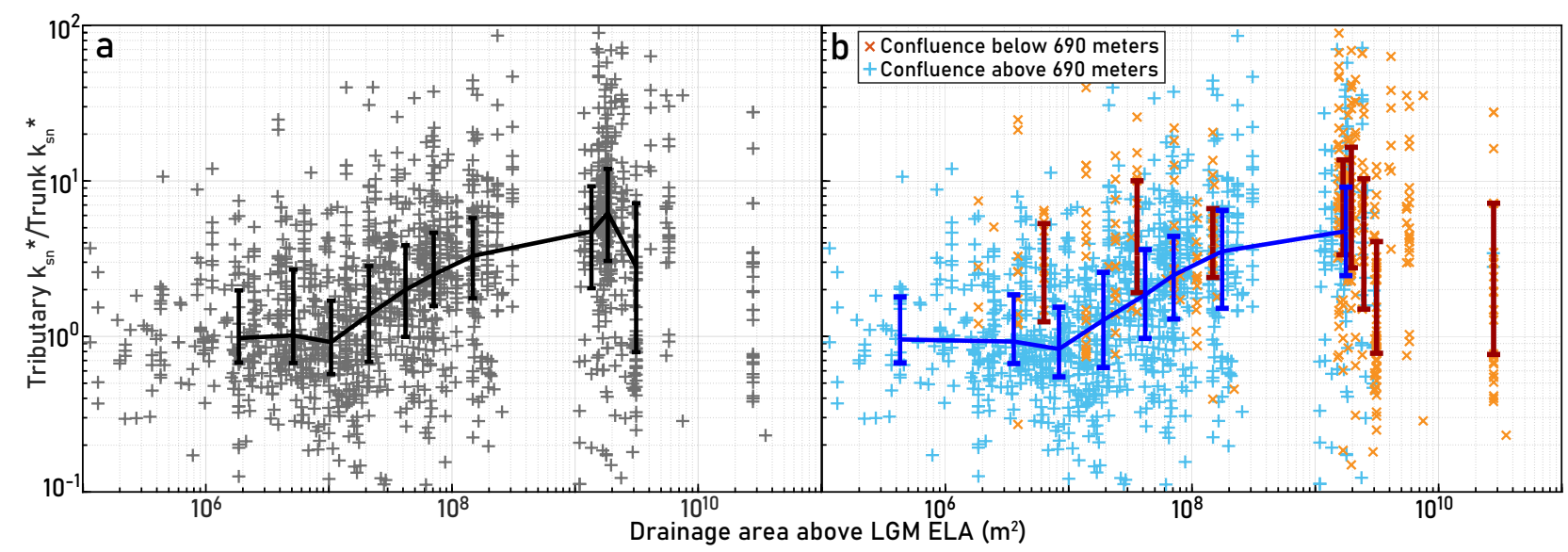

Figure 3. (a) $k_{s n}$ ratios between tributaries and trunk streams measured at confluences versus upstream area above the LGM ELA in the trunk stream. Bin centers are median values, edges are upper and lower quartiles. (b) $k_{s n}$ ratios at confluences separated into those above and below 690 meters, the elevation of the 1981 Bhote Koshi outburst flood discharge rollover point. We use 690 meters as an approximate elevation of the Himalayan Physiographic Transition (PT) in major river channels, to test for the influence of GLOF erosion on valley geometry above vs. below the PT. Spearman's rank correlation coefficient (Spearman's $\rho$ ), which tests for a potentially nonlinear monotonic relationship, for data above 690 meters is $\rho=0.441$ with $P<0.0001$. We also conducted a two-sample Kolmogorov-Smirnov test for the distributions of $k_{s n}$ ratios with above-ELA drainage areas between $10^{7}-10^{8} \mathrm{~m}^{2}(\mathrm{n}=488)$ and $10^{9}-10^{10} \mathrm{~m}^{2}(\mathrm{n}=155)$ to determine if the samples come from significantly different distributions, and found the empirical CDF for the first group is larger with $P<0.0001$. 
https://doi.org/10.5194/esurf-2021-54

Preprint. Discussion started: 3 August 2021

(c) Author(s) 2021. CC BY 4.0 License.

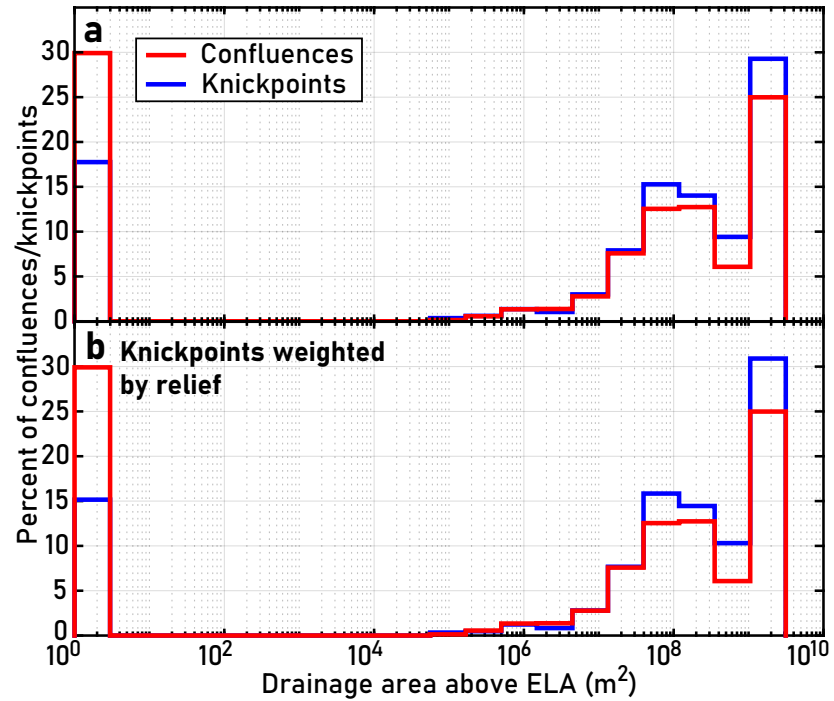

Figure 4. (a) Distribution of knickpoints $(n=5970)$ and confluences $(n=3062)$ between 1 st and 2nd and 4th or higher order rivers with respect to the area of terrain above the ELA drained by the trunk stream. Knickpoints included in the analysis are located on a 1st or 2nd order tributary within $2 \mathrm{~km}$ of a confluence with a 4th or higher order trunk stream. Area is log-binned, the lowest area bin contains only knickpoints and confluences where the trunk stream does not drain any terrain above the ELA. See Methods for criteria for identifying knickpoints. (b) Same as 4A, but knickpoints are weighted by their relief. For both the relief-weighted and non-weighted knickpoint distributions, we conducted two-sample Kolmogorov-Smirnov tests for the distributions of knickpoints versus confluences with respect to above-ELA drainage areas and found the empirical CDF for the confluences is larger with $P<0.0001$. 
https://doi.org/10.5194/esurf-2021-54

Preprint. Discussion started: 3 August 2021

(c) Author(s) 2021. CC BY 4.0 License.

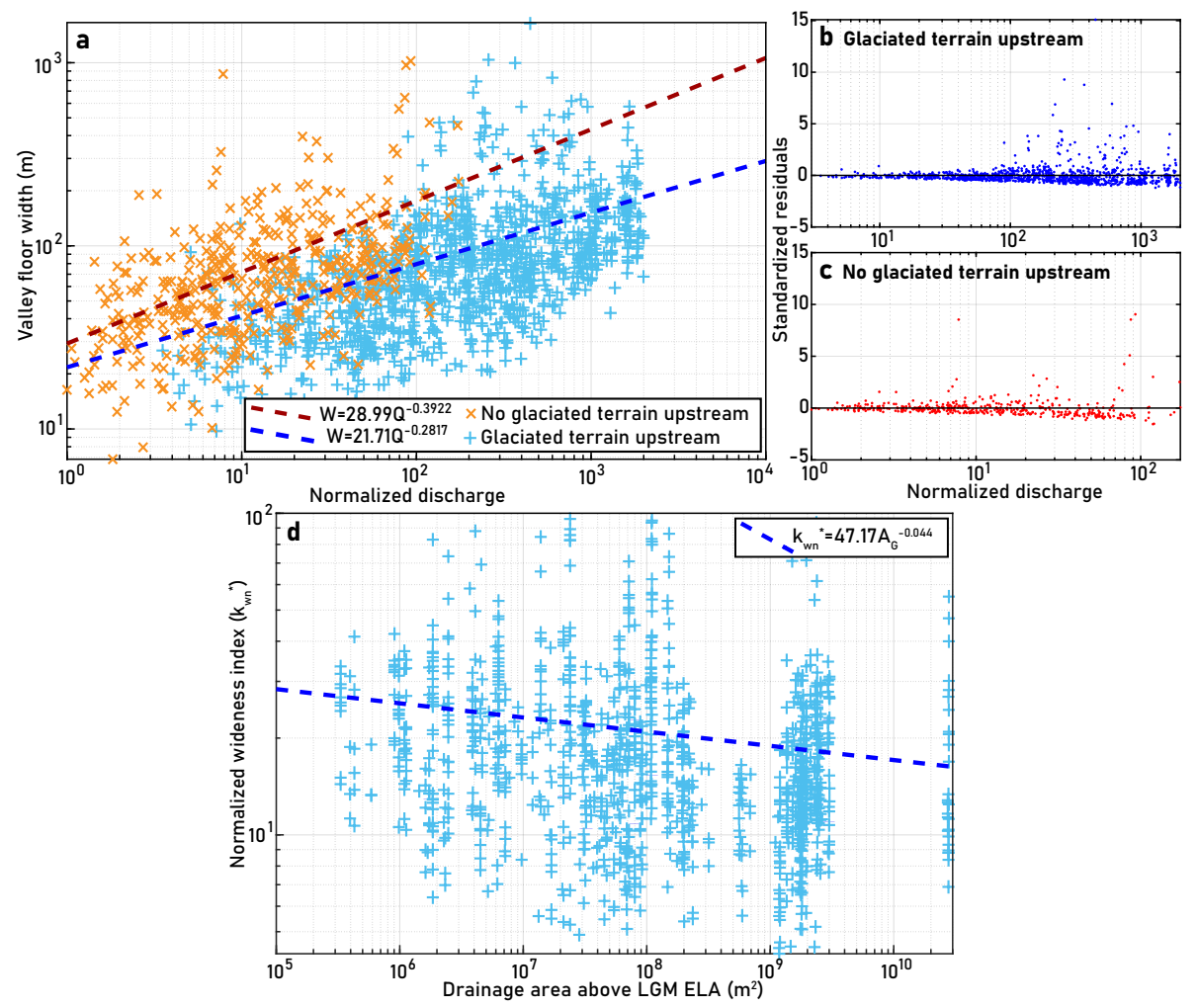

Figure 5. (a) Valley floor width versus discharge for rivers with and without headwaters above the LGM ELA, with power-law fits for valley wideness. Locations of valley width measurements are shown in Supplemental Figure 1. (b-c) Residuals plots for power-law fits shown in Figure 5A. (d) Normalized wideness $\left(k_{w n}^{*}\right)$ versus contributing drainage area above the LGM ELA for valley width measurements in blue from Figure 5A. Here, AG refers to drainage area above the ELA. Spearman's $\rho=-0.2116$ with $P<0.0001$. We conducted a two-sample Kolmogorov-Smirnov test for the distributions of $k_{w n}^{*}$ ratios with above-ELA drainage areas between $10^{7}-10^{8} \mathrm{~m}^{2}(\mathrm{n}=332)$ and $10^{9}-10^{10}$ $\mathrm{m}^{2}(\mathrm{n}=378)$ and found the empirical CDF for the latter group is larger with $P<0.0001$. Fits shown here were calculated using the "nlinfit" function in Matlab. 
https://doi.org/10.5194/esurf-2021-54

Preprint. Discussion started: 3 August 2021

(c) Author(s) 2021. CC BY 4.0 License.

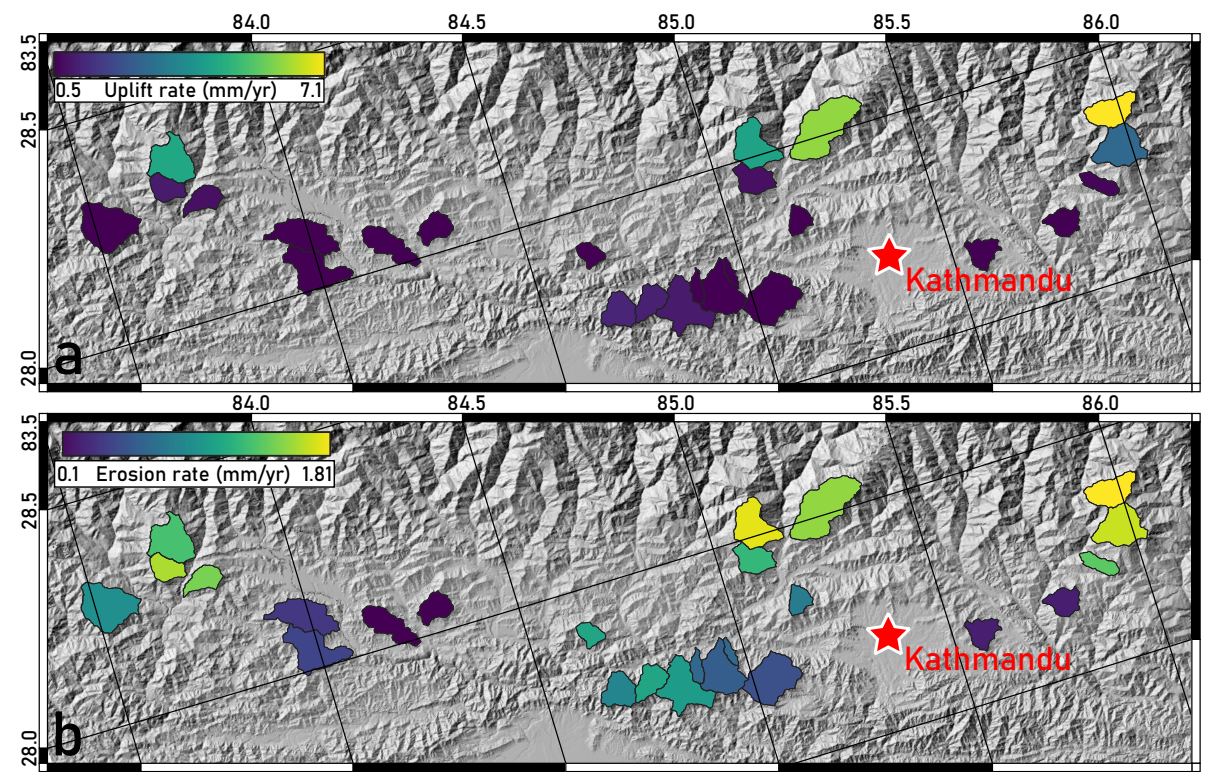

Figure 6. (a) Estimated uplift rate for basins with no or minimal drainage area above the LGM ELA (Lavé and Avouac, 2001). (b) Beryllium10-derived basin-averaged denudation rates for the same basins (Godard et al., 2014) 
https://doi.org/10.5194/esurf-2021-54

Preprint. Discussion started: 3 August 2021

(c) Author(s) 2021. CC BY 4.0 License.

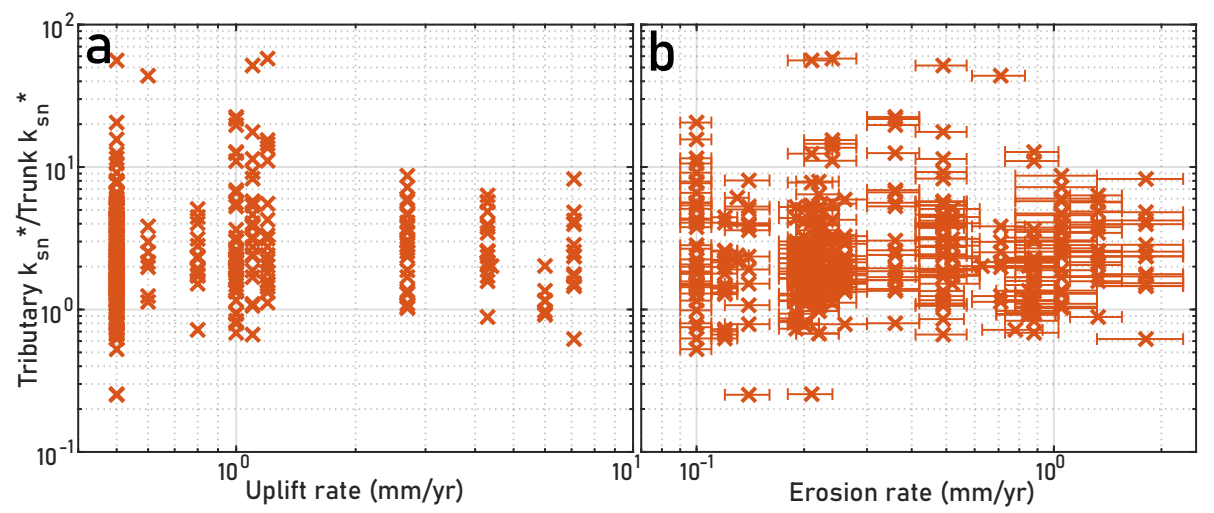

Figure 7. Adjusted normalized steepness index ratios between tributaries and trunk streams vs. uplift and denudation rates in basins identified in Figure 6 (a) $k_{s n}^{*}$ ratios between tributaries and trunk streams measured at confluences versus uplift rates shown in Figure 6 (Lavé and Avouac, 2001). Spearman's $\rho=0.1051$ with $P=0.0384$. (b) Same $k_{s n}^{*}$ ratios against Beryllium-10-derived denudation rates (Godard et al., 2014). Spearman's $\rho=0.0650$ with $P=0.2017$. 
https://doi.org/10.5194/esurf-2021-54

Preprint. Discussion started: 3 August 2021

(c) Author(s) 2021. CC BY 4.0 License.

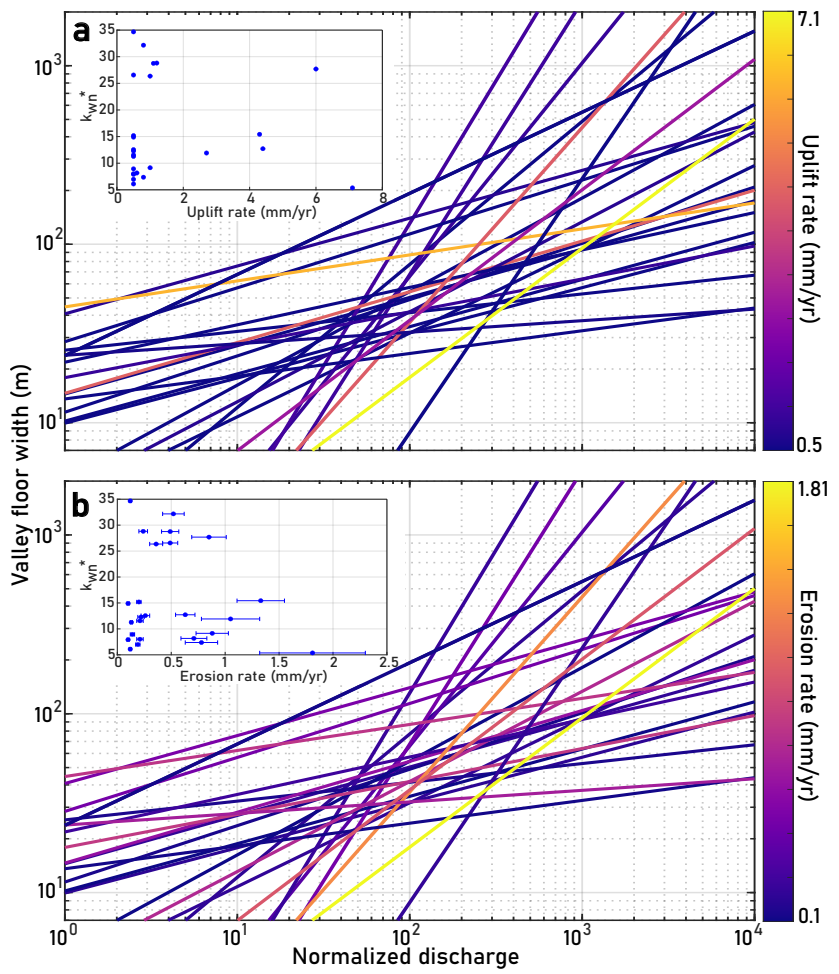

Figure 8. Best-fit lines for valley floor width vs. discharge for basins shown in Figure 6. (a) Lines show best-fit solutions for kw and b in Equation 6 and are colored by estimated uplift rate for the basin (Lavé and Avouac, 2001). Spearman's $\rho=0.2614$ with $P=0.2069$ for $b$ vs. uplift rate. Inset: $k_{w n}^{*}$ versus uplift rate. Spearman's $\rho=0.3257$ with $P=0.3257$. (b) Lines show best-fit solutions for kw and b in Equation 6 and are colored by Beryllium-10-derived denudation rate for the basin (Godard et al., 2014). Spearman's $\rho=0.1289$ with $P=0.5390$ for b vs. denudation rate. Inset: $k_{w n}^{*}$ versus denudation rate. Spearman's $\rho=0.0758$ with $P=0.7187$. 